\title{
Cytotoxicity Assessment of Organotin(IV) (2-Metoxyethyl) Methyldithiocarbamate Compounds in Human Leukemia Cell Lines
}

\section{NURUL FARAHANA KAMALUDIN ${ }^{\star 1}$, SITI AISHAH ZAKARIA ${ }^{1}$, NORMAH AWANG ${ }^{1}$, RAPIDAH MOHAMAD ${ }^{2}$ and NORRAPHAT UTTRAPHAN PIM ${ }^{2}$}

\author{
${ }^{1}$ Environmental Health and Industrial Safety Programme, School of Diagnostic and Applied \\ Health Sciences, Faculty of Health Sciences, Universiti Kebangsaan Malaysia, Jalan \\ Raja Muda Abdul Aziz, 50300 Kuala Lumpur, Malaysia. \\ ${ }^{2}$ Biomedical Science Programme, School of Diagnostic and Applied Health Sciences, \\ Faculty of Health Sciences, Universiti Kebangsaan Malaysia, Jalan Raja Muda \\ Abdul Aziz, 50300 Kuala Lumpur, Malaysia. \\ ${ }^{*}$ Corresponding author E-mail : nurulfarahana@ukm.edu.my \\ http://dx.doi.org/10.13005/ojc/330420
}

(Received: April 21, 2017; Accepted: June 25, 2017)

\begin{abstract}
Dibutyltin(IV) (2-methoxyethyl) methyldithiocarbamate (Compound 1) and tricyclohexyltin(IV) (2-methoxyethyl) methyldithiocarbamate (Compound 2) were used to evaluate their cytotoxicity against three human leukemic cell lines namely Jurkat E6.1, K562, and HL-60. The cytotoxicity of these compounds was assessed using MTT assay for treatment duration of 24 hours. The morphological changes were also observed upon the induction of these compounds with the $\mathrm{IC}_{50}$ value for 24 hours. Both compounds demonstrated high cytotoxicity towards the cell lines tested, with $\mathrm{IC}_{50}$ values of 0.14-1.30 $\mu \mathrm{M}$ (Jurkat E6.1), 0.06-0.18 $\mu \mathrm{M}$ (HL-60) and 5.20-5.40 $\mu \mathrm{M}$ (K562). The morphological changes of the cell lines induced by both compounds mostly showed characteristics of cell death via apoptosis. In conclusion, both compounds exhibited good cytotoxicity towards the cell lines tested. However, further studies are needed to identify the exact mode of cell death and the mechanisms of action of these compounds in induced human leukemic cell lines.
\end{abstract}

Keywords: Organotin, Dithiocarbamates, Cytotoxic, Leukemia, Apoptosis.

\section{INTRODUCTION}

Leukemia is a type of cancer that is formed in the bone marrow tissues, causing the formation of cancerous blood cells (Harmon, 2011). According to Cancer Research (2015), leukemia can be categorized as either acute or chronic, depending on the growth rate of the leukemic cells. Acute leukemia is a fast-growing cancer that usually gets worse quickly. In contrast, chronic leukemia is a 
slower-growing cancer that gets worse slowly over time and usually no symptom is detected at the early stages of the disease. Leukemia is also classified according to the type of cells involved. According to Hozumi and Metcalf (1985), leukemia involving myeloid cells is called myelogenous leukemia. Myeloblasts are immature blood cells that would normally become granulocytes or monocytes. On the other hand, leukemia that involves lymphocytes is called lymphocytic leukemia. Based on the above classifications, the types of leukemia generally can be divided into four main categories which are acute lymphoblastic leukemia, acute myeloid leukemia, chronic lymphoblastic leukemia and chronic myeloid leukemia (Bozzone, 2009).

The methods of treatment for cancer vary and depend on the types of cancer involved. According to Wust et al., (2002), the main cancer treatment methods are surgery, radiotherapy and chemotherapy. Surgery works best for removal of localized tumor, in which the cancer cells have yet to spread to other parts of the body (Baskar et al., 2012), whereas radiotherapy and chemotherapy are more effective for metastasized tumors (Cancer Research, 2016). Radiotherapy is a cancer treatment method that uses radiation such as $\mathrm{X}$-rays or gamma rays from radioactive substance to kill cancer cells (Baskar et al., 2012). Radiotherapy can be classified into two types which are external beam radiation therapy and internal radiation therapy. External beam radiation therapy comes from a machine that aims radiation at a specific part of cancer in the body and internal radiation therapy is done by putting the source of radiation inside the body close to the cancer cells (Cox et al., 1995). As for chemotherapy, drugs are used to kill cancer cells, which is an effective way to kill fast-growing cancer cells. However, this particular treatment may also cause side effects to other normal and healthy cells (National Cancer Institute, 2013). In their study, Meirow and Nugent (2001) stated that chemotherapy drugs enter the blood circulation system to destroy leftover cancer cells that may still remain after treatment with surgery or radiotherapy. Chemotherapy is often used to treat leukemia, of which one of the drugs is arsenic trioxide or Trisenox, and it is effective in treating acute promyelocytic leukemia (Wilson et al., 2002). According to Cai et al., (2000), arsenic trioxide induces leukemic cell death via apoptosis.

Cell death may be described by two wellcharacterized mechanisms, which are apoptosis and necrosis (Goran et al., 2005). The mechanisms of apoptosis include membrane blebbing, cell shrinkage, nuclear fragmentation and chromatin condensation. In a different manner, necrosis includes swelling of cells, disruption of membranes, and lysis of the nuclear chromatin. The apoptotic process does not cause inflammation such as in necrosis (Fadok et al., 1992; Goran et al., 2005). According to Yamaguchi et al., (2007), a compound that can induce cell death via apoptosis has the potential to be developed into anti-cancer drugs.

Several types of cancer cells have developed resistance towards the current chemotherapeutic drugs such as cisplatin, meaning that new anticancer drugs are crucially needed to combat cancer. In recent years, much attention has been paid among researchers towards organotin(IV) compounds due to their strong cytotoxicity towards cancerous cells (Awang et al., 2011). According to Pellerito et al., (2006), organotin compounds are highly toxic even at low concentrations. Organotin(IV) compounds are characterized by the presence of at least one covalent C-Sn bond (Awang et al., 2011; Pellerito et al., 2006). The compounds are classified as mono-, di-, tri- and tetraorganotin(IV) depending on the number of alkyl (R) or aryl (Ar) group that are attached to the Sn(IV) atom. Organotin(IV) compounds are frequently used in biomedicine and also for commercial purposes (Awang et al., 2011). The dithiocarbamates $\left(\mathrm{R}_{2} \mathrm{NCS}_{2}-\right)$ are half-amides of dithiocarbonic acid and sulphur analogues of carbamates $\left(\mathrm{R}_{2} \mathrm{NCO}_{2}-\right)$. In medicine, dithiocarbamates are used in chemotherapy and also as an antidote for metal poisoning (Robertson and Orrenius, 2000). Currently, organotin(IV) dithiocarbamate compounds have attracted researchers due to their ability to cause cytotoxic effects towards various types of cancerous cells (Awang et al., 2013). According to Awang et al. (2011), organotin(IV) dithiocarbamates have the general formula of $\mathrm{R}_{n} \mathrm{Sn}\left(\mathrm{S}_{2} \mathrm{CNR}^{\prime} \mathrm{R}^{\prime \prime}\right)_{4-n}\left(\mathrm{R}, \mathrm{R}^{\prime}\right.$ and $\mathrm{R}$ " represents alkyl or aryl groups; while $\mathrm{n}$ refers to the number of alkyl or aryl groups that attach 
to the $\mathrm{Sn}(\mathrm{IV})$ atom). These compounds have the potential to be developed into new chemotherapeutic agents due to their good anti-proliferative activity as observed in in-vitro studies.

A recent study conducted by Kamaludin et al., (2013) proved that triphenyltin(IV) $\mathrm{N}$-butyl- $\mathrm{N}$-phenyldithiocarbamate compound can cause high cytotoxic effects in Jurkat E6.1 cells with $\mathrm{IC}_{50}$ value of $0.4 \mu \mathrm{M}$. Another study conducted by Awang and Baba (2012) showed that dibutyltin(IV) with $\mathrm{N}$-alkylcyclohexyldithiocarbamate compound exhibited in-vitro cytotoxicity towards the human leukemic promyelocites tested upon. Their study also showed that the HL-60 cell line treated with the same compound demonstrated $\mathrm{CD}_{50}$ values of lower than $1.00 \mu \mathrm{g} / \mathrm{mL}$. In 2011, a study conducted by Awang et al., also proved that dibutyl- and triphenyltin(IV) benzylisopropyldithiocarbamate compounds can cause high cytotoxic effect on thymoma murine lymphoblastic leukemia cells, WEHI 7.2, human Chang liver cells and hepatocarcinoma HepG2 cells with the $I_{50}$ values obtained within the range of $0.6-7.0 \mu \mathrm{M}$. Pellerito et al. (2006) tested six derivatives of dibutyltin(IV) and one derivative of triphenyltin(IV) compounds against seven cancer cell lines of human origin, MCF-7 (mammary cancer), EVSA-T (mammary cancer), WiDr (colon cancer), IGROV (ovarian cancer), M19 (melanoma), MEL A498 (renal cancer) and H226 (lung cancer). The results showed that all compounds displayed high cytotoxic effects against the seven types of cancer cell lines tested. The $I D_{50}$ values obtained for the six derivatives of dibutyltin(IV) compounds were between $25 \mathrm{ng} / \mathrm{mL}$ to $478 \mathrm{ng} / \mathrm{mL}$, while the $I_{50}$ values obtained for triphenyltin(IV) compounds were in the range of $6 \mathrm{ng} / \mathrm{mL}$ to $30 \mathrm{ng} / \mathrm{mL}$.

For this study, the cytotoxic potency of a series of newly synthesized organotin(IV) (2-methoxyethyl) methyldithiocarbamate compounds, which are dibutyltin(IV) (2-methoxyethyl) methyldithiocarbamate (Compound 1) and tricyclohexyltin(IV) (2-methoxyethyl) methyldithiocarbamate (Compound 2) against three human leukemic cell lines namely Jurkat E6.1, K562 and HL-60 cells, are identified.

\section{MATERIALS AND METHODS}

\section{Compounds}

A series of organotin(IV) (2-methoxyethyl) methyldithiocarbamate compounds, which were dibutyltin(IV) (2-methoxyethyl) methyldithiocarbamate (Compound 1) and tricyclohexyltin(IV) (2-methoxyethyl) methyldithiocarbamate (Compound 2) were obtained from School of Chemical Science and Food Technology, Faculty of Science and Technology, Universiti Kebangsaan Malaysia, Bangi, Selangor, Malaysia. The reaction mechanism in synthesizing Compound 1 and Compound 2 were showed in Figure 1 and Figure 2, respectively. The characterization data of both compounds have been comprehensively described by our group previously (Mohamad et al., 2016).

\section{Cell Culture and Reagents}

Three human leukemic cell lines: Jurkat E6.1, K562, and HL-60 cells were purchased from the American Type Culture Collection (ATCC) and were cultured at Biocompatibility and Toxicology Lab, Faculty of Health Sciences, UKM Kuala Lumpur. The Jurkat E6.1 cells were maintained in Roswell Park Memorial Institute 1640 (RPMI 1640) supplemented with L-glutamine, sodium bicarbonate $\left(\mathrm{NaHCO}_{3}\right)$, $1 \%$ penicillin and streptomycin and 10\% Foetal Bovine Serum (FBS) (GIBCO, USA). The K562 cells and HL-60 were maintained in Iscove's Modified Dulbecco's (IMDM) supplemented with L-glutamine, sodium bicarbonate $\left(\mathrm{NaHCO}_{3}\right), 1 \%$ penicillin and streptomycin and varying concentrations of Foetal<smiles>[R16][CH][NH2+]CCOC</smiles>

Fig. 1: Reaction mechanism of dibutyltin(IV) (2-methoxyethyl) methyldithiocarbamate (Compound 1), where $\mathrm{R}=\mathrm{Bu}$ Source: Mohamad et al. (2016) 


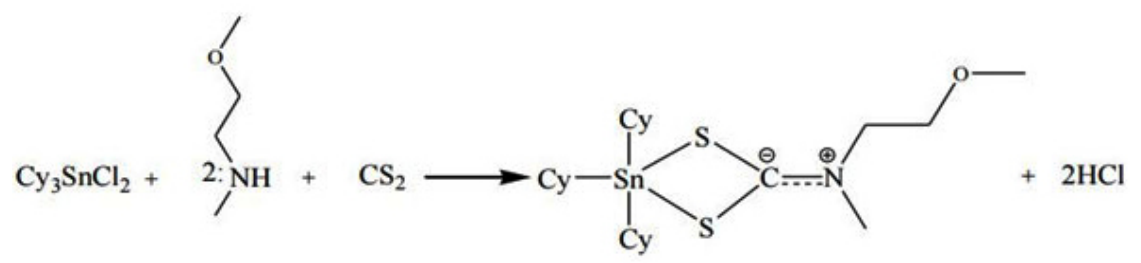

Fig. 2: Reaction mechanism of tricyclohexyltin(IV) (2-methoxyethyl) methyldithiocarbamate (Compound 2)

Source: Mohamad et al. (2016)

Bovine Serum (FBS) (GIBCO, USA) for each type of cell $-10 \%$ for $\mathrm{K} 562$ cells and $20 \%$ for HL- 60 cells. All cell lines were grown at $37^{\circ} \mathrm{C}$ in a humidified atmosphere with $5 \% \mathrm{CO}_{2}$ and were in exponential phase of growth at the time of inclusion in cytotoxicity assays.

\section{Assessment of Cytotoxicity Using MTT Assay}

Cellular viability for the three human leukemic cell lines namely Jurkat E6.1 cells, K562, and HL-60 cells were determined by using 3-(4,5dimethylthiazol-2-yl)-2,5-diphenyltetrazolium bromide (MTT) assay. The assay was conducted as described by Mosmann (1983) with slight modifications. Both Compound 1 and Compound 2 were dissolved in dimethyl sulphoxide (DMSO), diluted in culture media and then used to treat the cell lines. The percentage of DMSO present in any well was less than $0.1 \%$. The three human leukemic cell lines were treated with both organotin(IV) compounds along with doxorubicin hydrochloride (DOX) which acts as the positive control. The cells were treated using seven different concentrations $(0.156,0.313,0.625,1.250$, $2.500,5.000$ and $10.000 \mu \mathrm{M})$ for 24 hours. Then, the cells were seeded in sterile 96 well flat-bottomed plates (Nunc, Denmark) at a density of $2 \times 10^{6}$ cells $\mathrm{mL}^{-1}$ and grown in $5 \% \mathrm{CO}_{2}$ at $37^{\circ} \mathrm{C}$. In metabolically active cells, MTT is reduced by the mitochondrial enzyme succinate dehydrogenase to form insoluble purple formazan crystals that are subsequently solubilized. Next, the optical density (OD) was measured spectrophotometrically. The cells treated by the compounds were assayed by the addition of $20 \mu \mathrm{L}$ of $5 \mathrm{mg} \mathrm{mL}^{-1} \mathrm{MTT}$ in $0.1 \mathrm{M}$ phosphate buffer saline (PBS) of $\mathrm{pH} 7.4$, following incubation for 4 hours at $37^{\circ} \mathrm{C}$. Then, $180 \mathrm{~mL}$ of supernatant was carefully removed from each well and $180 \mu \mathrm{L}$ of DMSO was added to dissolve the formazan crystals. Plates were agitated using orbital shaker for 3 to 5 minutes to ensure complete dissolution of crystals and the OD was measured at $570 \mathrm{~nm}$ using ELISA Microplate Reader (Labsystem Multiscan Multisoft, Finland). Each compound concentration had five replicates per assay and each experiment was carried out on at least three separate occasions. The $I_{50}$ values were determined based on the plotted graphs for each compound and used as a parameter to compare the relative cytotoxicity of each test compound.

\section{Morphological Changes Observation}

The three human leukemic cell lines and the doxorubicin hydrochloride (positive control) were treated by using the $\mathrm{IC}_{50}$ obtained from the MTT assay after 24 hours treatment. All cells were cultured in 6 well culture plates at a concentration of $1 \times 10^{6}$ cells $\mathrm{mL}^{-1}$ and then incubated at $37^{\circ} \mathrm{C}$ with $5 \% \mathrm{CO}_{2}$ supply. The morphological changes of all the cells were then observed under an inverted light microscope at a 40x magnification.

\section{Statistical Analysis}

Statistical evaluations of the percentage of viable cells along with the concentration of compounds used to treat the cells were calculated using Statistical Package for Social Sciences (SPSS) version 22.0 by employing One-Way ANOVA (analysis of variance). A probability of 0.05 or less was deemed statistically significant $(p<0.05)$.

\section{RESULTS}

Cytotoxic Effects of Organotin(IV)(2-Methoxyethyl) Methyldithiocarbamate Compounds Using MTT Assay

HL-60 Cells

The graph of cytotoxic effects against HL-60 cells upon treatment by organotin(IV) 
(2-methoxyethyl) methyldithiocarbamate compounds for 24 hours treatment duration is shown in Figure 3.

The graph in Figure 3 shows the cytotoxic effects on HL-60 cells upon induction with Compound 1 and Compound 2 after 24 hours treatment duration. Based on the graph, it can be seen that both compounds were able to reduce the viability of HL-60 cells. For both compounds, the highest concentration used was $2.00 \mu \mathrm{M}$ where as the lowest was $0.03 \mu \mathrm{M}$. The cell viability (\%) for Compound 1 at concentrations $0.03 \mu \mathrm{M}, 0.06 \mu \mathrm{M}, 0.13 \mu \mathrm{M}, 0.25$ $\mu \mathrm{M}, 0.50 \mu \mathrm{M}, 1.00 \mu \mathrm{M}$ and $2.00 \mu \mathrm{M}$ were $78.10 \pm$ $4.54 \%, 46.21 \pm 3.28 \%, 36.20 \pm 2.88 \%, 26.00 \pm$ $1.40 \%, 21.28 \pm 1.58 \%, 18.70 \pm 1.41 \%$ and 14.63 $\pm 2.18 \%$ respectively. For Compound 2, the cell viability (\%) at concentrations $0.03 \mu \mathrm{M}, 0.06 \mu \mathrm{M}$, $0.13 \mu \mathrm{M}, 0.25 \mu \mathrm{M}, 0.50 \mu \mathrm{M}, 1.00 \mu \mathrm{M}$ and $2.00 \mu \mathrm{M}$ were $86.92 \pm 5.43 \%, 70.53 \pm 3.66 \%, 58.52 \pm$ $3.59 \%, 26.95 \pm 2.29 \%, 20.36 \pm 0.44 \%, 16.78 \pm$ $0.82 \%$ and $12.40 \pm 1.43 \%$ respectively. The $\mathrm{IC}_{50}$

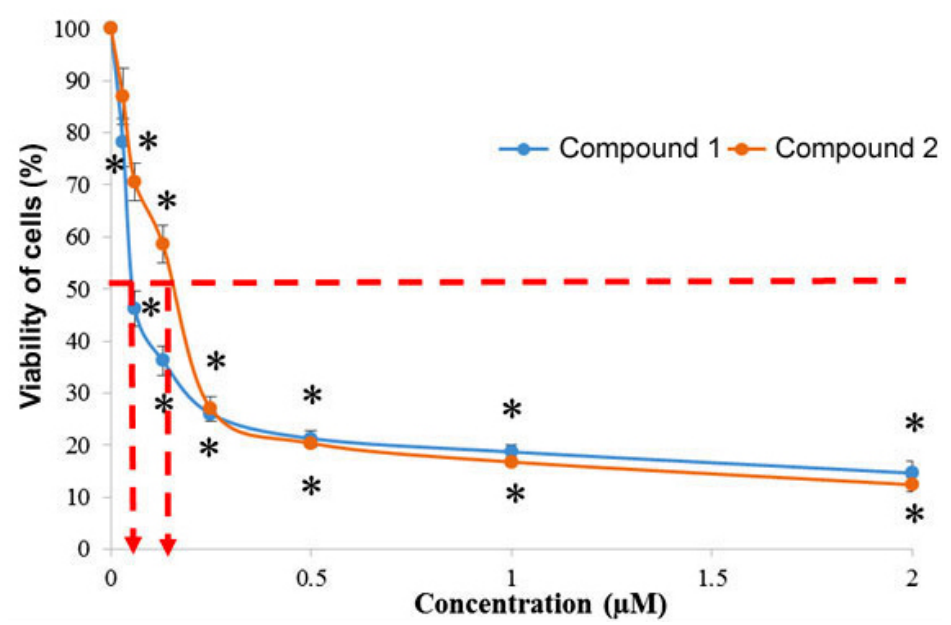

Fig. 3: Cytotoxic effects on HL-60 cells induced by Compound 1 and Compound 2 after 24 hours treatment duration. The data shows the cell viability (\%) \pm S.E.M obtained from three separate repeated experiments.

*The difference in significance level $(p<0.05)$ compared to the negative control

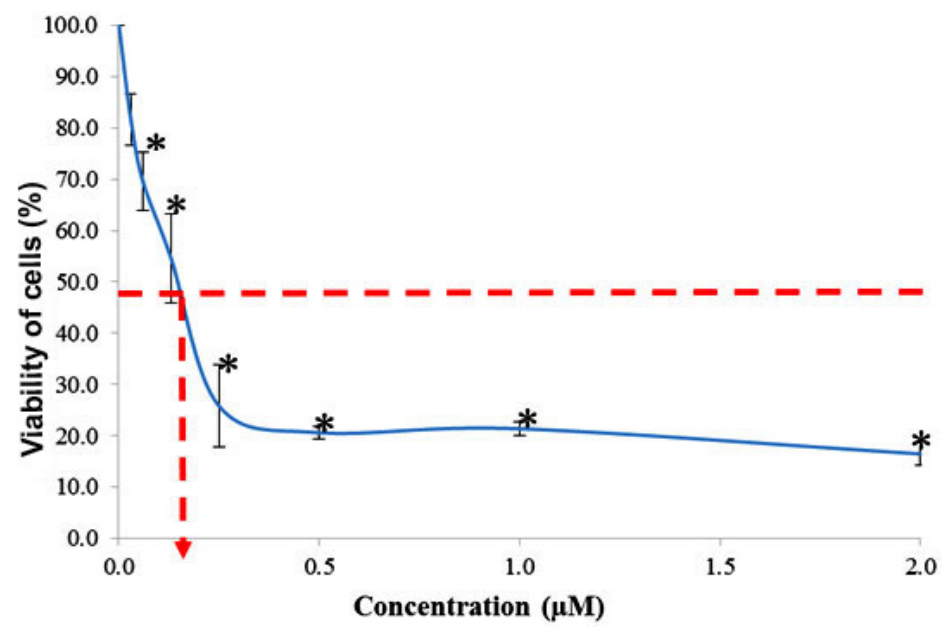

Fig. 4: Cytotoxic effects on Jurkat E6.1 cells induced by Compound 1 after 24 hours treatment duration. The data shows the cell viability $(\%) \pm$ S.E.M obtained from three separate repeated experiments.

*The difference in significance level $(p<0.05)$ compared to the negative control 
values obtained from the HL-60 cells induced by Compound 1 and Compound 2 are shown in Table 1.

\section{Jurkat E6.1 Cells}

The graph for the cytotoxic effects on Jurkat E6. 1 cells after 24 hours treatment using dibutyltin(IV) (2-methoxyethyl) methyldithiocarbamate compound (Compound 1) is shown in Figure 4. Based on the figure, it was found that Compound 1 was able to reduce the viability of Jurkat E6.1 cells. The highest concentration used was $2.00 \mu \mathrm{M}$ and the lowest concentration used was $0.03 \mu \mathrm{M}$. The viability of the cells (\%) treated with Compound 1 at concentrations $0.03 \mu \mathrm{M}, 0.06 \mu \mathrm{M}, 0.13 \mu \mathrm{M}, 0.25 \mu \mathrm{M}, 0.50 \mu \mathrm{M}, 1.00$ $\mu \mathrm{M}$ and $2.00 \mu \mathrm{M}$ were $81.55 \pm 4.99 \%, 69.55 \pm 5.69$ $\%, 54.63 \pm 8.66 \%, 25.78 \pm 7.99 \%, 20.61 \pm 1.20 \%$, $21.37 \pm 1.32 \%$ and $16.47 \pm 2.25 \%$ respectively.

Figure 5 shows the graph of cytotoxic effects on the Jurkat E6.1 cells upon induction with tricyclohexyltin(IV) (2-methoxyethyl)

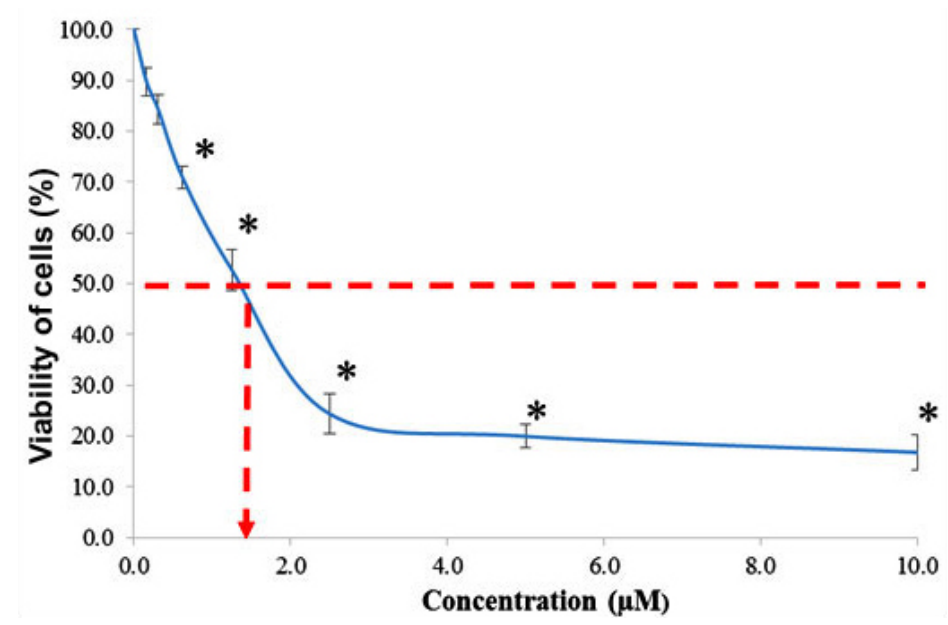

Fig. 5: Cytotoxic effects on Jurkat E6.1 cells induced by Compound 2 after 24 hours treatment duration. The data shows the cell viability (\%) \pm S.E.M obtained from three separate repeated experiments.

*The difference in significance level $(p<0.05)$ compared to the negative control

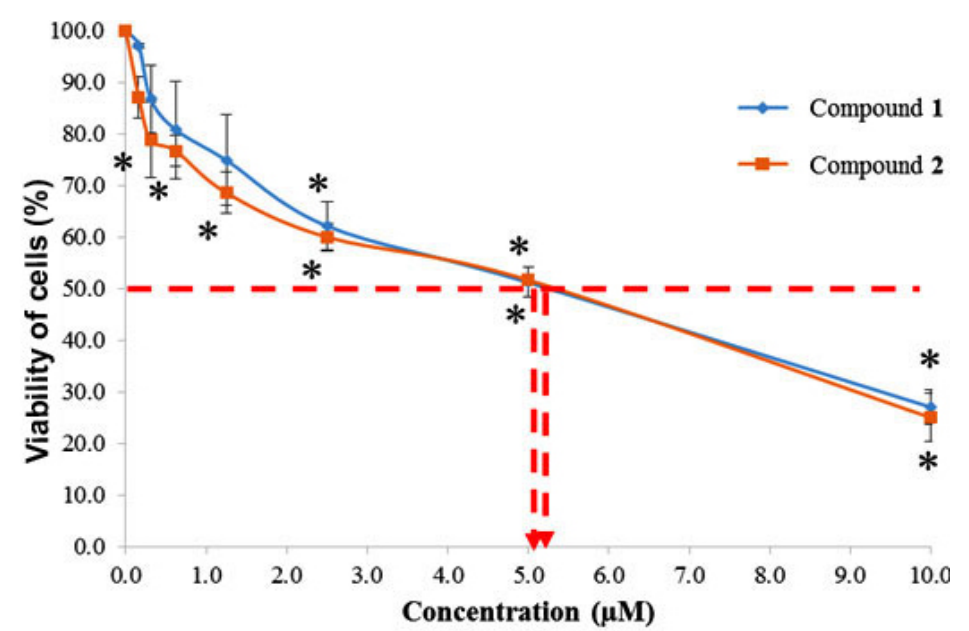

Fig. 6: Cytotoxic effects on K562 cells induced by Compound 1 and Compound 2 after 24 hours treatment duration. The data shows the cell viability (\%) \pm S.E.M obtained from three separate repeated experiments.

*The difference in significance level $(p<0.05)$ compared to the negative control 
methyldithiocarbamate compound (Compound 2) for 24 hours treatment duration. From the graph, it shows that Compound 2 was also able to reduce the viability of Jurkat E6.1 cells. The highest concentration used was $10.00 \mu \mathrm{M}$ and the lowest concentration used was $0.16 \mu \mathrm{M}$. The cell viability (\%) for Compound 2 at concentrations $0.16 \mu \mathrm{M}, 0.31$ $\mu \mathrm{M}, 0.62 \mu \mathrm{M}, 1.25 \mu \mathrm{M}, 2.50 \mu \mathrm{M}, 2.50 \mu \mathrm{M}, 5.00 \mu \mathrm{M}$ and $10.00 \mu \mathrm{M}$ were $89.76 \pm 2.73 \%, 84.28 \pm 2.96$ $\%, 70.89 \pm 2.11 \%, 52.66 \pm 3.97 \%, 24.33 \pm 4.00$ $\%, 19.93 \pm 2.30 \%$ and $16.77 \pm 3.53 \%$ respectively. The $I_{50}$ values obtained from the Jurkat E6.1 cells induced by Compound 1 and 2 are stated in Table 1.

\section{K562 Cells}

The graph in Figure 6 shows the cytotoxic effects on K562 cells upon induction with Compound 1 and Compound 2 after 24 hours treatment duration. Based on the graph, it can be seen that both compounds were able to reduce the viability of K562 cells. For both compounds, the highest concentration used was $10.00 \mu \mathrm{M}$ where as the lowest was $0.16 \mu \mathrm{M}$. The cell viability (\%) for Compound 1 at concentrations $0.16 \mu \mathrm{M}, 0.31 \mu \mathrm{M}, 0.62 \mu \mathrm{M}, 1.25$ $\mu \mathrm{M}, 2.50 \mu \mathrm{M}, 2.50 \mu \mathrm{M}, 5.00 \mu \mathrm{M}$ and $10.00 \mu \mathrm{M}$ were

Table 1: IC $C_{50}$ values for Compound 1, Compound 2 and DOX on HL-60, Jurkat E6.1 and K562 cells

\begin{tabular}{lccc}
\hline Compound & \multicolumn{3}{c}{$\mathrm{IC}_{50}$ values $(\mu \mathrm{M})$} \\
\cline { 2 - 4 } & $\mathrm{HL}-60$ & Jurkat E6.1 & K562 \\
\hline 1 & 0.06 & 0.14 & 5.20 \\
2 & 0.18 & 1.30 & 5.40 \\
DOX & 1.18 & 0.35 & 25.00 \\
\hline
\end{tabular}

$97.14 \pm 1.99 \%, 86.77 \pm 6.19 \%, 80.82 \pm 7.82 \%$, $74.90 \pm 5.70 \%, 62.16 \pm 0.84 \%, 51.21 \pm 2.66 \%$ and $27.06 \pm 3.98 \%$ respectively. For Compound 2, the cell viability (\%) at concentrations $0.16 \mu \mathrm{M}, 0.31$ $\mu \mathrm{M}, 0.62 \mu \mathrm{M}, 1.25 \mu \mathrm{M}, 2.50 \mu \mathrm{M}, 2.50 \mu \mathrm{M}, 5.00 \mu \mathrm{M}$ and $10.00 \mu \mathrm{M}$ were $87.15 \pm 4.00 \%, 78.82 \pm 7.29$ $\%, 76.74 \pm 2.94 \%, 68.60 \pm 4.02 \%, 60.02 \pm 2.66 \%$, $51.69 \pm 1.04 \%$ and $25.03 \pm 4.74 \%$ respectively. The $\mathrm{IC}_{50}$ values for the $\mathrm{K} 562$ cells induced by Compound 1 and Compound 2 compared to the positive control were stated in Table 1.

The statistical analysis showed that there is significant difference $(p<0.05)$ in terms of viability for the K562 cells treated with Compound 1 and Compound 2 at concentrations $2.50 \mu \mathrm{M}, 5.00 \mu \mathrm{M}$ and $10.00 \mu \mathrm{M}$ compared to that of the untreated cells after induction by Compound 1. However, the statistical analysis in terms of viability for the K562 cells treated with Compound 2 shows that there is no significant difference $(p>0.05)$ at concentration $0.16 \mu \mathrm{M}$ compared to that of the untreated cells after induction by Compound 2.

Morphological Changes of Jurkat E6.1, K562 and HL-60 cells upon The Induction of Organotin(IV) (2-Methoxyethyl) Methyldithiocarbamate Compounds

The morphological changes observed on the three human leukemic cell lines: HL-60, Jurkat E6.1 and K562 cells upon treatment with Compound 1 and Compound 2 are shown in Figures 7, 8 and 9. The $\mathrm{IC}_{50}$ values obtained for Compound 1 on $\mathrm{HL}-60$, Jurkat E6.1 and K562 cells were $0.06 \mu \mathrm{M}, 0.14 \mu \mathrm{M}$ and $5.20 \mu \mathrm{M}$ respectively whereas the $\mathrm{IC}_{50}$ values obtained for Compound 2 were $0.18 \mu \mathrm{M}, 1.30 \mu \mathrm{M}$ and $5.40 \mu \mathrm{M}$ respectively. As compared to cells without treatment, it was found that both compounds induced

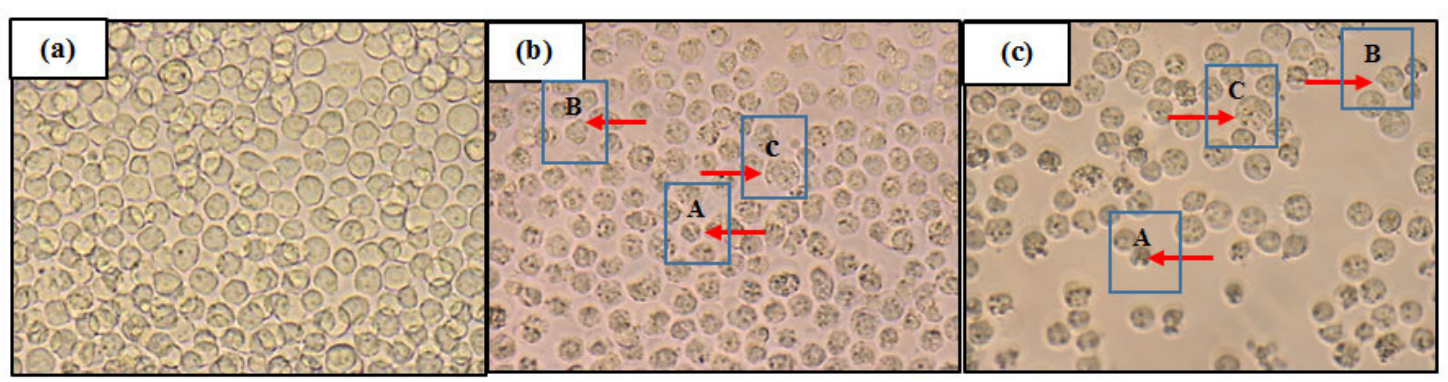

Fig. 7: Morphological changes of HL-60 cells (40x) - (a) Without treatment, (b) With treatment of Compound 1 for 24 hours and (c) With treatment of Compound 2 for 24 hours A: Cell shrinkage, B: Membrane blebbing, C: Cell swelling 
the characteristics of apoptosis towards all the tested cells, which are cell shrinkage, membrane blebbing and formation of apoptotic bodies. Necrosis was also observed on the cells induced by the compounds, which includes characteristics such as cell swelling and lysis.

\section{DISCUSSION}

The results obtained from this study indicated that both the organotin(IV) (2-methoxyethyl) methyldithiocarbamate compounds tested were able to reduce the cell viability (\%) of all the three human leukemic cell lines treated which were Jurkat E6.1, K562 and HL-60 cells for 24 hours treatment duration at different concentrations. According to Pellerito et al. (2006), the best incubation period for cell culturing on organotin(IV) toxicity study is between 24 to 48 hours. This study found that both Compound 1 and 2 produced $\mathrm{IC}_{50}$ values of less than $5 \mu \mathrm{g} / \mathrm{mL}(<8.90 \mu \mathrm{M})$ towards the three human leukemic cells lines treated. These findings showed that both compounds are highly toxic towards all three human leukemic cell lines treated, in line with a statement by Pellerito et al., (2006) who stated in their study that organotin compounds are highly toxic even at low concentrations. Other than that, the nature of dithiocarbamate compounds which show better solubility in organic solvents (lipophilic) than in water, helps in the process of transporting the organotin(IV) compounds across the cell membrane. Because of this, the lipophilic nature of organotin(IV) compounds could be one of the contributing factors of the intracellular interactions which induces their toxicity towards the cancerous cells (Huang et al., 2009). Dithiocarbamate compounds are highly versatile ligands towards the main group metals and their strong metal binding properties are directly related to the possession of two donor sulphur atoms. They act as inhibitors of enzymes which can significantly affect biological systems and thus induce cytotoxic effects towards cells (Mohamad et al., 2016).

The results obtained from the MTT assay showed that Compound 1 was able to reduce the cell viability percentage in all three human leukemic cell lines tested. However, the cell viability (\%) of Jurkat E6.1, K562 and HL-60 cells were lower compared to that of K562 cells. According to How et al., (2008), compounds with $\mathrm{IC}_{50}$ values less than $5 \mu \mathrm{g} / \mathrm{cm}^{3}$ can be classified as highly toxic compounds. Compound 1 produced $\mathrm{IC}_{50}$ values less than $5 \mu \mathrm{g} / \mathrm{mL}(<8.90 \mu \mathrm{M}$ of Compound 1) against the three leukemic cells tested, which clearly proved that it is very toxic to the cancerous cells. Even so, there is significant difference $(p<0.05)$ in $I C_{50}$ values for Compound 1 on the Jurkat cells $(0.14 \mu \mathrm{M})$ compared to those of the $\mathrm{K} 562(5.20 \mu \mathrm{M})$ and $\mathrm{HL}-60(0.06 \mu \mathrm{M})$ cells. However, there is no significant difference $(p>0.05)$ in the $\mathrm{IC}_{50}$ values for Compound 1 between Jurkat E6.1 cells $(0.14 \mu \mathrm{M})$ and $\mathrm{HL}-60$ cells $(0.06 \mu \mathrm{M})$ and also between HL-60 cells $(0.06 \mu \mathrm{M})$ and K562 cells (5.20 $\mu \mathrm{M})$. This signifies that the $\mathrm{IC}_{50}$ values for Compound 1 in Jurkat cells and HL-60 cells were lower than that of $\mathrm{K} 562$ cells. In short, it can be said that Compound 1 was more toxic towards Jurkat E6.1 cells and HL-60 cells compared to K562 cells.

Compound 2 also showed the ability to reduce the percentage of viable cells in all three human leukemic cell lines tested. However, the cell viability of Jurkat E6.1, K562 and HL-60 cells were lower than that of K562 cells. Compound 2, like Compound 1, produced IC $\mathrm{C}_{50}$ values less than $5 \mu \mathrm{g} / \mathrm{mL}$ $(<9.40 \mu \mathrm{M}$ of Compound 2) against the three types

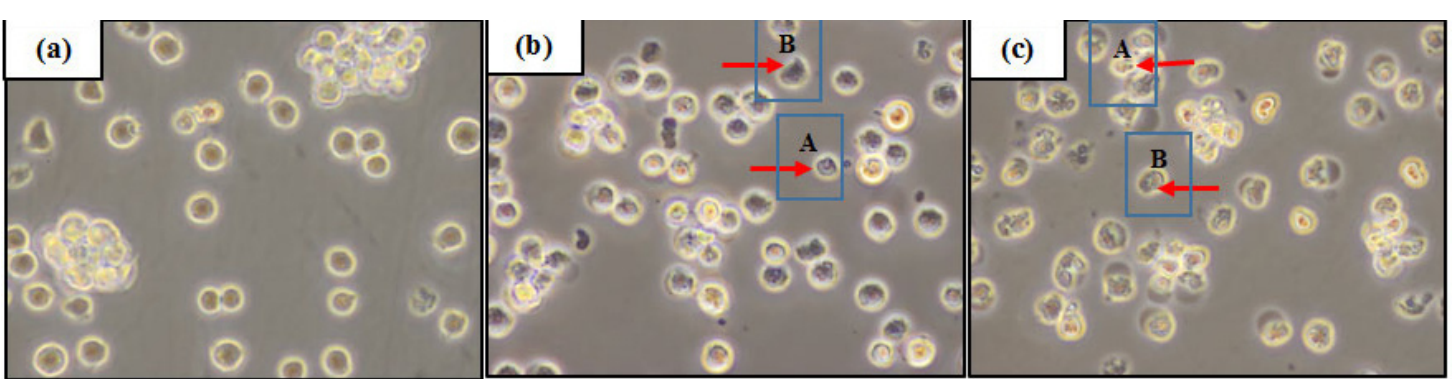

Fig. 8: Morphological changes of Jurkat E6.1 cells (40x) - (a) Without treatment, (b) With treatment of Compound 1 for 24 hours and (c) With treatment of Compound 2 for 24 hours A: Cell shrinkage, B: Membrane blebbing 
of leukemic cells tested. Based on the classification of toxicity of compounds as stated by How et al., (2008), Compound 2 can also be classified as a highly toxic compound. There is significant difference $(p<0.05)$ in the $\mathrm{IC}_{50}$ values of Compound 2 between Jurkat E6.1 cells $(1.30 \mu \mathrm{M})$ and K562 cells (5.40 $\mu \mathrm{M})$, and also between HL-60 cells $(0.18 \mu \mathrm{M})$ and $\mathrm{K} 562$ cells $(5.40 \mu \mathrm{M})$. However, there is no significant difference $(p>0.05)$ in the $\mathrm{IC}_{50}$ values for Compound 2 between Jurkat E6.1 cells $(1.30 \mu \mathrm{M})$ and HL-60 cells $(0.18 \mu \mathrm{M})$. These values obtained concluded that the $\mathrm{IC}_{50}$ values for Compound 2 in Jurkat E6.1 cells and HL-60 cells were lower than that of the K562 cells, proving that Compound 2 was more toxic towards Jurkat E6.1 and HL-60 cells compared to K562 cells.

Based on the $\mathrm{IC}_{50}$ values obtained, Compound 1 demonstrated better cytotoxicity than Compound 2, of which may be influenced by the different number of alkyl groups attached to the Sn(IV) atom. According to Syng-ai et al., (2002), the nature and the number of alkyl groups attached to the $\mathrm{Sn}(\mathrm{IV})$ atom influences the cytotoxicity of organotin (IV) compounds. In this study, the different degrees of cytotoxicity demonstrated by the compounds used must be influenced by different number of substitution groups bound to the Sn(IV) atom. Compound 2 has a longer alkyl group chain as compared to Compound 1. The alkyl substituent group attached to the $\mathrm{Sn}(\mathrm{IV})$ atom in Compound 1 consists of 4 carbon atoms, whereas Compound 2 has 6 carbon atoms, which goes in line with a study conducted by Ray et al., (2000) stating that the cytotoxicity of compounds will reduce with the increasing length of alkyl group chain.
The $\mathrm{IC}_{50}$ values obtained from this study for Jurkat E6.1 cells and HL-60 cells were lower than the $\mathrm{IC}_{50}$ values of K562 cells for both types of compounds treated, indicating that both compounds showed stronger cytotoxicity towards Jurkat E6.1 cells and HL-60 cells compared to K562 cells. This also specified that Jurkat E6.1 cells and HL-60 cells were more sensitive towards the compounds treated compared to K562 cells. The reason for this could be the resistance of chronic myelogenous leukemia (CML) towards many chemotherapy agents as stated by Wang et al., (2011). According to Bhamidipati et al., (2013), K562 cells are myeloid leukemia cells with high resistance factor, of which only specific treatments could inhibit its tyrosine kinase activities due to the $\mathrm{BCR} / \mathrm{ABL}$ protein formation in its structure. Imatinib, which inhibits specific tyrosine kinase activities, is the current anti-cancer agent for treatment of CML (Bhamidipati et al., 2013). Unfortunately, some patients with CML treated by Imatinib have developed resistance and also side effects to the agent (Kantarjian et al., 2011).

This study and also a previous study conducted by Awang et al., (2011) proved that dibutyltin(IV) benzylisopropyldithiocarbamate compounds showed high cytotoxic effects towards the cells tested. In their study, Awang et. al., (2011) discovered that the $\mathrm{IC}_{50}$ values obtained from the cells studied were less than $10.00 \mu \mathrm{M}$, which were: Chang liver cells $(2.50 \mu \mathrm{M})$ and hepatocarcinoma HepG2 cells $(7.00 \mu \mathrm{M})$. In addition to that, the results from their study also supported a study conducted by Kamaludin et al., (2013) which showed that dibutyltin(IV) butylphenyldithiocarbamate compounds have high cytotoxic effects towards

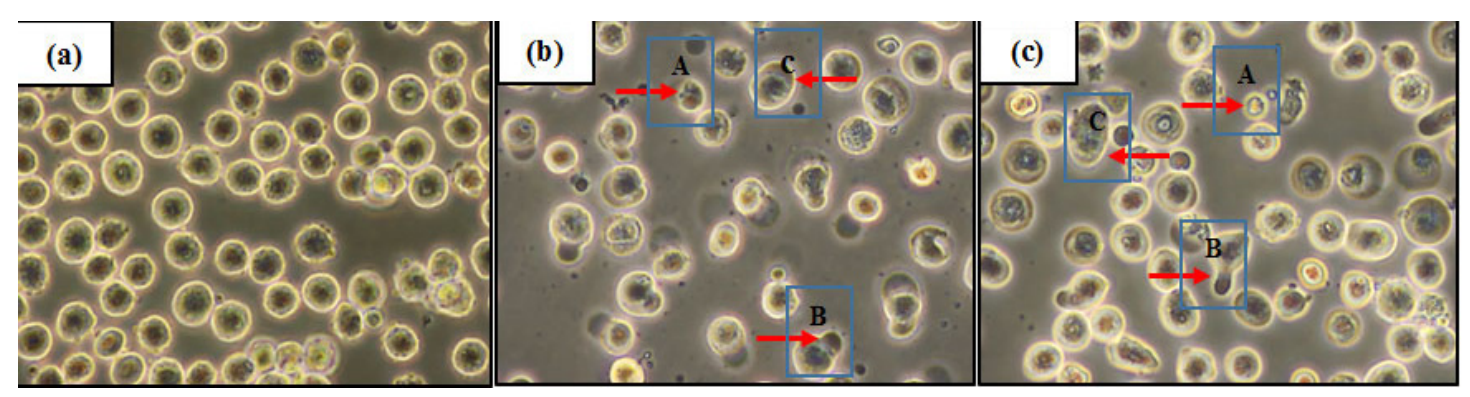

Fig. 9: Morphological changes of K562 cells (40x) - (a) Without treatment, (b) With treatment of Compound 1 for 24 hours and (c) With treatment of Compound 2 for 24 hours A: Cell shrinkage, B: Membrane blebbing,C: Cell swelling 
Jurkat E6.1 and K562 cells tested as well, with $\mathrm{IC}_{50}$ values of less than $5 \mu \mathrm{g} / \mathrm{mL}(<8.70 \mu \mathrm{M})$. In their study, the $I_{50}$ values obtained for dibutyltin(IV) butylphenyldithiocarbamate on Jurkat E6.1 cells was ranged between $0.50-0.80 \mu \mathrm{M}$, while for $\mathrm{K} 562$ cells from 3.90-5.30 $\mu \mathrm{M}$.

Doxorubicin hydrochloride (DOX), which was used as the positive control in this study, was also able to produce cytotoxic effects towards all the three types of leukemic cells tested in this study. Compound 1 and 2 demonstrated comparable cytotoxicities with DOX in Jurkat E6.1 and HL-60 cells and much stronger effect in K562 cells. This proved that the two new organotin(IV) (2-methoxyethyl) methyldithiocarbamate compounds, which are dibutyltin(IV) (2-methoxyethyl) methyldithiocarbamate (Compound 1) and tricyclohexyltin(IV) (2-methoxyethyl) methyldithiocarbamate (Compound 2 ), have great potential in being developed into anticancer agents.

Morphologically, Jurkat E6.1, K562, and HL-60 cells tested showed apoptotic characteristics of cell death after treatment with both organotin(IV) compounds at $\mathrm{IC}_{50}$ doses for 24 hours. According to Pellerito et al., (2006), some of the morphological changes that occur in apoptosis are membrane blebbing, cells shrinkage, chromatin condensation and formation of apoptotic bodies. Cell death can also occur through necrosis which includes cell swelling, and this can be seen in K562 and HL-60 cells after treatment with Compound 1 and 2. All in all, it can be concluded that Jurkat E6.1, K562, and HL-60 cells demonstrated cell death via apoptosis when induced with organotin(IV) compounds, supporting a study conducted by Costa et al., (2011) which showed that the diorganotin (IV) and triorganotin (IV) compounds used in the study were able to cause cell death via apoptosis on A375 cells. A study conducted by Awang et al., (2015) also showed that a series of triorganotin(IV) dithiocarbamate treated onto Jurkat E6.1 cells had induced apoptosis on the cancerous cells. However, the morphological changes observed in this study was not enough to conclude that the organotin(IV) compounds can induce apoptosis in all types of cancerous cells.

\section{CONCLUSION}

In conclusion, the two new organotin(IV) (2-methoxyethyl) methyldithiocarbamate compounds: dibutyltin(IV) (2-methoxyethyl) methyldithiocarbamate (Compound 1) and tricyclohexyltin(IV) (2-methoxyethyl) methyldithiocarbamate (Compound 2) possess the ability to reduce cell viability of Jurkat E6.1, K562, and HL-60 cells tested in this study whereby both compounds had demonstrated high cytotoxicity towards the cancerous cells. However to compare, Compound 1 displayed better cytotoxicity on all three cell lines compared to Compound 2. In terms of cytotoxicity toward the different types of cancerous cells, both compounds were more toxic on Jurkat E6.1 and HL-60 cells compared to K562 cells. Through morphological changes observation, it was observed that all the three types of leukemic cells showed apoptotic cell death characteristics, indicating that these organotin(IV) (2-methoxyethyl) methyldithiocarbamate compounds have the potential to be developed into anti-leukemic agents.

\section{ACKNOWLEDGEMENT}

We would like to thank Universiti Kebangsaan Malaysia (GGPM-2016-061) for supporting this study and offer the utmost sincere thanks to the management of the Biocompatibility and Toxicology Lab, Faculty of Health Sciences, Universiti Kebangsaan Malaysia (UKM) Kuala Lumpur for providing the essential laboratory facilities which enabled this study to take place. We would also like to channel our gratitude to the laboratory assistants of Faculty of Health Sciences for their much needed technical support.

\section{REFERENCES}

1. Harmon, D. E. Rosen Pub Inc. 2011.

2. Hozumi, M.; Metcalf, D. Critical reviews in oncology/hematology. 1985, 3(3), 235-277.
3. Bozzone M.D. Infobase Pub Inc. 2009.

4. Wust, P.; Hildebrandt, B.; Sreenivasa, G.; Rau, B.; Gellermann, J.; Riess, H.; Felix, R.; 
Schlag, P.M. The lancet oncology. 2002, 3(8), 487-497.

5. Baskar, R.; Lee, K.A.; Yeo, R.; Yeoh, K. Internatioal Journal of Medical Sciences, 2012, 9(3), 193-199.

6. Mierow, D.; Nugent, D. Human Reproduction Update. 2011, 7(6), 535-543.

7. Wilson, H.M.J.; Hyman, M.S.; Janet, S.L.; Jack, S.; Samuel, W. Cancer Research. 2002, 62, 3893-3903.

8. $\quad$ Cai, X.; Shen, Y.L.; Zhu, Q.; Jia, P.M.; Yu, Y.; Zhou, L.; Huang, Y.; Zhang, J.W.; Xiong, S.M.; Chen, S.J.; Wang, Z.Y.; Chen, Z.; Chen, G.Q. Macmillan Publishers. 2000, 14, 262-270.

9. Goran, B.; Aleksandar, N.; Marija, B.; Ivanka, S.; Rade, A.; Vuka, K. Facta Universitatis. 2005, 12, 6-11.

10. Fadok, V.A.; Voelker, D.R.; Campbell, P. A.; Cohen, J.J.; Bratton, D. L.; Henson, P.M. Journal of Immunology. 1992, 148, 22072216.

11. Yamaguchi, Y.; Passeron, T.; Watabe, H.; Yasumoto, K.I.; Rouzaud, F.; Hoashi, T.; Hearing, V.J. Journal of Investigative Dermatology. 2007, 127(5), 1217-1225.

12. Awang, N.; Kamaludin, F.N.; Ghazali, R.A. Pakistan Journal of Biological Sciences.2011, 14(15), 768-774.

13. Pellerito, C.; Nagy, L.; Pellerito, L.; Szorcsik, A. Journal of Organometallic Chemistry. 2006, 691, 1733-1747.

14. Robertson, J.D.; Orrenius, S. Critical Reviews in Toxicology. 2000, 30(5), 609-627.

15. Awang, N.; Shahidi, M.S.; Hamid, A.; Kamaludin, F.N. Malaysian Journal of Health Sciences. 2013. 11(1), 2532.

16. Kamaludin, N.F.; Awang, N.; Baba, I.; Hamid,
A.; Chan, K.M. Pakistan Journal of Biological Sciences. 2013, 16(1), 12-21.

17. Awang, N.; Baba, I. Sains Malaysiana.2012, 41(8), 977-982.

18. Mohamad, R.; Awang, N.; Kamaludin, F.N. Research Journal of Pharmaceutical, Biological and Chemical Science. 2016, 7(2), 1920-1925.

19. Huang, W.; Ding, Y.; Miao, Y.; Liu, M.Z.; Li, Y.; Yang, G.F. European journal of medicinal chemistry. 2009, 44(9), 3687-3696.

20. How, F.N.F.; Crouse,K.A.; Tahir, M.I.M.; Tarafder, M.T.H.; Cowley, A.R. Polyhedron. 2008, 27, 3325-2229.

21. Syng-ai, C.; Basu Baul, T.S.; Chatterjee, A. Mutation Research. 2002, 513(1), 1- 230.

22. Ray, D.; Sarma, K.D.; Antony, A. IUMBM Life. 2000, 49, 519-525.

23. Wang, K.C.; Yang, Y.W.; Liu, B.; Sanyal, A.; Corces-Zimmerman, R.; Chen, Y.; Wysocka, J. Nature. 2011, 472(7341), 120-124.

24. Bhamidipati, P.K.; Kantarjian, H.; Cortes, J.; Cornelison, A.M.; Jabbour, E. Therapeutic advances in hematology. 2013, 4(2), 103117.

25. Kantarjian, H.M.; Hochhaus, A.; Saglio, G.; De Souza, C.; Flinn, I.W.; Stenke, L.; Yeow-Tee, G.; Rosti, G.; Nakamae, H.; Gallagher, N.J.; Blakesley, R.E.; Larson, R.A.; Hughes, T.P.; Hoenekopp, A. The lancet oncology. 2011, 12(9), 841-851.

26. Costa, M.A.;Zito, F.; Emma, M.R.; Pellerito, L.; Fiore, T.; Pellerito, C.; Barbieri, G. International Journal of Oncology. 2011, 38, 693-700.

27. Awang, N.; Yousof, M.A.S.N.; Rajab, F.N.; Kamaludin, F.N. Journal of Applied Pharmaceutical Science. 2015, 5(1), 7-11. 